\title{
CHALLENGES IN DISTANCE LEARNING DURING THE PANDEMIC SITUATION OF CORONAVIRUS (COVID-19): A PERSPECTIVE FROM BANGLADESH
}

\author{
Md. Shahidul Islam \\ Divisional Officer \\ Service Engineering Division \\ Bangladesh Forest Research Institute, Chittagong, Bangladesh \\ E-mail: engr.shahidul.islam@gmail.com \\ Md. Shahnur Azad Chowdhury \\ Associate Professor \\ Department of Business Administration \\ Int'1 Islamic University Chittagong, Bangladesh \\ E-mail: tipu_iiuc@yahoo.com \\ Sultana Akter \\ Assistant Professor \\ Department of Business Administration \\ Int'1 Islamic University Chittagong, Bangladesh \\ E-mail: sa_maya@rocketmail.com \\ A. B. M. Yasir Arafat \\ Lecturer \\ Department of Computer Science and Engineering \\ Int'1 Islamic University Chittagong, Bangladesh \\ E-mail: abmya89@yahoo.com \\ Md. Kazi Golam Azam \\ Assistant Professor \\ Department of Business Administration \\ Int'1 Islamic University Chittagong, Bangladesh \\ E-mail: mdkgazam@iiuc.ac.bd
}

\begin{abstract}
The purpose of the study is to identify the socio-psychological challenges that influence the distance learning education performance to be recognized and evaluated in the COVID-19 pandemic situation to develop the planning and utilization strategy for smooth and high-quality online uninterrupted teaching and learning environment in the future. A systematic random sampling survey method is used to collect information from 100 respondents on a ten-point Likert scale $(1=$ Least significant and $10=$ Most significant to the factor of online learning). The survey
\end{abstract}


response data were collected from online class experienced teachers and students (masters and graduate) from business school and science and engineering school of Int'l Islamic University Chittagong, Bangladesh (longitude 91.720902539062 and Latitude 22.495181427788) in the March-April 2021. Descriptive analysis, factor analysis, and structural equation model are used from the collected survey data by using IBM SPSS Statistics 20 and IBM SPSS AMOS 22 software to identify factors that have a significant influence on performance. The study result shows that personal factor, task assignment factor, and course factor have significant positive contribution and technical factor has a significant negative contribution to the performance in the online education. But perceive factor and social factor have no significant contribution to the performance in online education.

Keywords: Internet in Education, Online Class, Policymaker, Socio-Psychological Challenge.

JEL Classification Codes: I21, C38, C12.

\section{INTRODUCTION}

The effect of the Covid 19 crisis has affected the educational practices of approximately 150 million students around the world. All of these students are on the verge of joining the job market after completing their studies in a short period of time. The abrupt halt in all of these students' educational progress has put a strain on their emotional, economical, social, personal, and physical well-being. Furthermore, the entire educational system has come to a halt, posing the most significant danger to the nation's future. The simplest and most common solution to this issue is to move to an online education system. Our country's leadership, as well as the Ministry of Education, have taken sufficient positive steps in this regard. In the midst of this crisis, the online education system has provided students hope and has become a viable educational option. Despite the fact that many have questioned its quality and compared it to the physical structure, it has provided an opportunity to consider the topic more deeply. However, today's learners all over the world are searching for a versatile education format that can be accessed at any time and from any place. Online learning opportunities are in high demand, particularly among a group of learners who face specific challenges, and education providers are responding positively (Schrum \& Hong, 2002). In all countries and institutions, the standard and popularity of online education vary. Learning and teaching styles, as well as personal encouragement and infrastructure, are all important factors in ensuring a smooth online teaching experience. Some colleges and universities have been able to show effective online teaching delivery (Fredericksen et al., 2000). Despite some challenges, online teaching and learning provide a solution to an inevitable issue. After the outbreak of the coronavirus, educational institutions at all levels around the world have had to shut down their usual face-to-face distribution systems on campus. Some colleges and universities perform research programs online, while others do not. Many that are actively performing research activities online are confronted with a number of issues. Especially in developing countries, where information technology is not yet widely available and the internet is not easily accessible from anywhere and by anyone. Both students and instructors may have disadvantages, and both may face difficulties in continuing online classes. The usage and acceptance of the internet are rising by the day, suggesting a brighter future for online teaching and learning (Muilenburg \& Berge, 2005). As a result, the obstacles that students face must be recognized and evaluated in order to establish a plan for smooth and high-quality online teaching and learning. 


\section{OBJECTIVES OF THE STUDY}

Education is a major sector for every nation. Learning can't be interrupted for maintaining continuous development. Digitization has been initiated in every sector of the country. So, education should also deserve attention for being digitized. It has become emergent to run online education in the current situation of COVID-19 as there are no other alternatives. As this is a new experience so there are a lot of limitations to the online education system. To make it fruitful a long way to travel in his line with necessary modifications by identifying the challenges. This study attempts to explore the possible challenges in online education.

To conduct the study successfully, the following objectives has been identified:

- To give an overview of the current situation of online education in Bangladesh

- To explore the challenges in the field of online education in Bangladesh

\section{LITERATURE REVIEW}

Continuation of disasters creates the necessity of using technologies that helps to cope up with the change (Meyer \& Jones, 2011) particularly Communication technologies such as e-learning tools (Tull, 2017). The coronavirus disease (COVID-19), a disaster for human living systems in the whole world mostly affected the economic system, health care system, and education system. The following review of literature states the changing pattern, tools for the digital education system, challenges, and finally some suggestions for the improvement of the online education system. To control the transmission of COVID-19, Staying home and strong Lockdown strategies have been adopted (Sintema, 2020) and these strategies were implemented nationally from 1 August 2020 (Palden, 2020). Almost all governments of countries around the world have introduced similar goals like imposing strict lockdown, restricting immigration, social/physical distancing, and avoidance of on-campus face-to-face learning (Gonzalez et al., 2020). Moreover, Globalization, privatization, and liberalization of education have significantly worsened because of the confined program relating to academic activities and restricted mobility among the countries during this pandemic (Mishra et al., 2020). During the lockdown, teachers are instructed to teach through online learning platforms (Abidah et al., 2020). The immediate shift of physical classrooms into e-classrooms has changed the pedagogical approach of educators in order to cope with changed situations and new market conditions. Institutional adaptability with online education at a massive level becomes more concern irrespective of quality education during this hurdle time period (Carey, 2020). To satisfy the unprecedented demand, faculty members made a change in their courses in short order with negligible formal training, and on the other hand, students have affected through various ways like problems in learning new technology, loss of internship, locational disadvantage, etc. (Govindarajan \& Srivastava, 2020). Furthermore, The forced shift of the education system requires capacity improvement of information technology due to the introduction of automation, machine learning, and the development of artificial intelligence (Krishnamurthy, 2020). Online learning may be defined as gaining learning experience in a variant environment by using mobile phone and laptop devices connecting with the instructor through the internet from anywhere in the world (Singh \& Thurman, 2019). Again, online learning is known as open learning, web-based learning, m-learning, blended learning, etc. which assures common efficiency of learning through computer devices that connect teacher and students from any place by internet (Cojocariu et al., 2014). Before the pandemic, most of the institutions use face to face learning approach within campus area but the eruption of COVID-19 divert conventional method into the 
digital method in our education system which incorporates online lecture, online examination, teleconferencing, digital open books, and almost all interaction at virtual environments (Strielkowski, 2020; Kumar, 2020). Moreover, the education environment experienced the use of Online platforms like Zoom, Google classroom, and other virtual learning platforms along with various social media such as Messenger, Whatsapp, we-chat, Telegram, etc. for the first time (Pokhrel \& Chhetri, 2021). There are some benefits of the online education system, (Means et al., 2013) claim that online learning might be more fruitful than the traditional approach of learning. Again, students from distant locations can easily connect with minimal cost and time. However, online education becomes challenging for the economically disadvantaged group as socioeconomic conditions are not the same for all learners in society (Pokhrel \& Chhetri, 2021). Most of the students rely on android mobile facing tremendous problems from remote access due to poor internet connectivity, depression anxiety, and lack of proper learning environment (Kapasia et al., 2020), and learners with hearing-impaired face challenges while using e-learning (Manzoor, 2020). Moreover, learners from third world countries face challenges in the suddenly changed education system as it requires to cope up with limited technical infrastructure, academic incompetency, and finally limited. Therefore, effective and efficient use of resources is crucial to continue education during a pandemic. Dhawan (2020) suggested that institutional focus goes to better use of technology with low cost in maintenance and procurement along with internet speed, access to the internet, security feature, available laboratories, and improvement in digital literacy. Some educational models like a model for educational emergencies treatment (MEET) for managing and restoring educational operations (Karalis, 2020) as well as holistic teacher education systems (Zhu \& Liu, 2020) are advocated for better support in the present and future teaching at the time of the similar type of natural disasters like COVID-19 pandemic.

Hence, Bangladesh is facing COVID-19 pandemic and passing through the shifted education system, so it requires research on a new education system which also supported by an above review of literature that will help smother management and distribution of education in an equal manner at present and future.

\section{Digital Bangladesh}

For the first time, the present government has adopted a plan to build a digital Bangladesh by 2021. the independence of Bangladesh was gained in 1971 through a bloody war, the half-century of its independence is being marked in 2021 and that is why it has touched all of us to dream of taking our beloved motherland to a special place during this time. So, the word digital Bangladesh has not become just a word. The government and the people of this country have all taken a big initiative to make it a reality. Bangladesh has currently gained the $57^{\text {th }}$ position in the world to launch Bangabandhu Satellite 1 from the Kenedy Space Center in the United States at 2.14 pm on May 11, 2018. However, the word digital Bangladesh was not just used as a computer-ready country. It is much more comprehensive. Digital Bangladesh means to create a modern Bangladesh using information and communication technology. The goal of Digital Bangladesh is to implement the country's commitment to education, health, employment, and poverty alleviation using all kinds of technologies. To reach this goal, it is very important to change our old mentality and think positively and innovatively. The keyword behind Digital Bangladesh is to ensure democracy, human rights, transparency, accountability, and justice for the people of the country and to make maximum use of technology for them. Its ultimate goal is to improve the quality of life of all types of people of all classes. The government has emphasized four specific issues for the implementation of Digital Bangladesh such as human resource development, people's 
involvement, civil services, and the use of information technology in daily life. As compared to many other countries in the world, Bangladesh has started the work of expansion of information technology late. So, Bangladesh stays far behind many other countries. Although in the past the importance of information and communication technology was not properly realized, now it is becoming very important. With the connection of submarine cable, it is now possible to provide a high-speed internet connection in our country. Due to the interest of the government, information technology infrastructure has started to develop in the country. Many Initiatives have been taken to provide internet service to remote areas by laying fiber-optic lines across the country. Even a decade and a half ago, the number of telephones in this country was negligible. Now it can be said without hesitation that every adult in this country has a phone at their hand. Adults have phones at their fingertips. Information service centers have been set up at the union level, post offices in remote areas have been converted into e-centers and mobile money orders have been provided. The Union Information Center, as well as the District Information Cell and the National Information Cell, is a major addition to the country's infrastructure. Work is being done regularly for registration of admission tests, knowing the results of public examinations, or buying train tickets through the mobile telephone. This look is proof of the fact that information and communication technology lessons have been added in schools and colleges. Computer science is being taught in colleges and universities of the country. The young generation of the country is building their own companies besides giving jobs to various software companies and a large number of young people are strengthening the economy of the country by outsourcing on a personal level.

The date of $12^{\text {th }}$ May 2018 is very important for us. On this day, Bangladesh, as the $57^{\text {th }}$ country in the world, launched its own satellite 'Bangabandhu Satellite-1' into space. In this, the country went one step further in the implementation of Digital Bangladesh. Using satellite will benefit education, medicine, agriculture, weather forecasting as well as Bangladesh's economic progress. The satellite can also be used for television services and national security. A new level will be added to the management of natural disasters anywhere in Bangladesh. In addition, due to the use of information and communication technology due to Bangabandhu Satellite, along with saving foreign currency, a large amount of foreign exchange income will also be possible. With this breakthrough in information technology, let no one think that we have already reached our goal - this is not true at all. In this way, we have a long way to go. Since most of the people in our country live in villages, the first step in building a digital Bangladesh is to bring these rural people under the purview of information and communication technology services. That is why now Bangladesh Government have to build a huge infrastructure to get the full benefits of information technology. In this case, skilled manpower is needed. The quality of education in schools, colleges, and universities needs to be enhanced and more students need to be trained in information and communication technology. E-governance should ensure transparency in all matters. The new generation needs to be encouraged to harness their innovative potential. There needs to be coordination between the university and the information and communication technology industry. Only then can we build a real digital Bangladesh.

\section{Education System in Bangladesh During COVID-19}

COVID-19, which carries the coronavirus, was first reported in late 2019 in China's Wuhan Province. Due to the rapid spread of the disease around the world, the WHO declared the March 11, 2020, global epidemic. Outbreaks appear to be exacerbated in Bangladesh. According to 
statistics there were confirmed cases of $787 \mathrm{~K}$, recovered $729 \mathrm{~K}$, and death cases 12310 as of 22.05.2021 in Bangladesh.

The disease is mainly spread by coughing, sneezing, and touching infected patients within 3 feet. As a result, it is very important to maintain social distance to get rid of this disease. The Bangladesh government has taken enough steps in this regard.

The time we are passing through the Covid crisis is a great challenging issue. Covid is forcing people to enter the virtual world and people are gradually getting used to the virtual world. For example, people are going to online health care without going to the doctor for medical services. In this way, moving from shopping to e-commerce, schooling to distance learning, and socialization to social distance is better for us due to the corona situation. Adapting to such a big change is a big challenge over the world.

Bangladesh has a broad education system consisting of 38.6 million students were 3.6 million in pre-primary, 18 million in primary, 13 million in secondary, and 4 million in tertiary level. According to the year 2018, 0.17 million educational institutions are ranging from primary to tertiary level, including 0.13 million primary schools. The economic growth of the country is integrally associated with strong educational achievement and learning outcomes and skills development. The COVID-19 pandemic pushed 1.6 billion children and youth out of school in 193 countries which is almost $90 \%$ of total enrolled students. Due to the rapid spread of the Corona epidemic worldwide, the Bangladesh government imposed a lockdown on the entire country from march 17, 2020. About 38.6 million students stopped their studies as the educational institution was closed for more than a year. It also resulted in the suspension of all primary school first-term examinations across the country, as well as the postponement of the Higher Secondary School Certificate (HSC) Examination (Grade 12/equivalent terminal exam) for the academic year. The country's learning and human capital growth are likely to suffer short-, medium-, and long-term consequences, if school closures and disruptions continue. As a result, the government of Bangladesh recognizes the importance of planning for and reacting to the COVID-19 pandemic in Bangladesh's educational system. Due to the outbreak of the coronavirus, major impacts on education in Bangladesh are as follows:

\section{- Incomplete learning due to discontinuation}

The academic progress of students would be disrupted due to long time absent from physical schooling. The overall scenario is affecting the school, college, or university yearly planned activities in the worst-case scenario, which could result in a one-year gap for all students.

- Creating problem of assessment

Because of the pandemic, physical learning programs and planned tests will be temporarily suspended, making it more difficult to increase learning outcomes or even sustain the number of students who achieve grade-level competencies. Simultaneously, authorities and teachers would struggle to find an appropriate alternative for national evaluations, given the lack of learning due to institutional closures and other factors.

- Faulty method for evaluation

During the covid 19 periods, some institutions try to start a virtual education system for adult students. Although conducting classes through various difficulties but no expected policy for evaluation has developed till now.

- Un-uniform learning system

Students from educated and wealthy families tend to be able to continue their education at home because they have access to computer technology, the internet, and other resources. 
This problem creates a learning gap between those students who do not have access to those services.

- The rate of dropout students is increasing

The anticipated global economic crisis caused by the pandemic, as well as its severe effect on household income, would increase the dropout rate, especially among girls and those from low-income or disadvantaged families.

- Creating depression in students who are going to have completed degrees

Students are suffering from depression and inferiority due to endless future uncertainty, they are mostly helpless to begin a new life career without finishing their degrees. On the other hand, they have to depend on the other of the family members.

- More difficulties for poor and rural student

These types of students are deprived of necessary digital opportunities such as smartphones, laptops, $4 \mathrm{G}$ networks, high costly internet, etc. This is also a new difficulty that poor and rural students don't know how to use android mobile efficiently. There are no available facilities for wireless internet connection i.e. Wi-Fi with low cost. As a result, students are dropping dawn in various level of education and also losing interest for next higher study. In an analysis of the Daily ProthomAlo there a greater increasing rate of forced child girl marriage in the rural area.

\section{Hypothesis 1}

\section{HYPOTHESIS}

Personal challenge has no significant effect on the Performance of online learning.

\section{Hypothesis 2}

Perceived challenge has no significant effect on the Performance of online learning.

\section{Hypothesis 3}

Task assignment challenge has no significant effect on the Performance of online learning.

\section{Hypothesis 4}

Technical challenge has no significant effect on the Performance of online learning.

\section{Hypothesis 5}

Social challenge has no significant effect on the Performance of online learning.

\section{Hypothesis 6}

Course challenge has no significant effect on the Performance of online learning.

\section{METHOD}

To study the challenge of online class during coronavirus (COVID-19) a survey questionnaire was developed from literature review and experience of authors. The developed survey questionnaire is pre-tested with 10 respondents and necessary corrections and modifications are made to finalize the final questionnaire. Now the finalized questionnaire is distributed to 100 respondents for the reply. In this research, data were collected on a questionnaire survey in the form of a ten-point Likert scale ranging from $1=$ Least significant to Performance of online learning and $10=$ Most significant to Performance of online learning. Data collection for this study began on the date 20 
March 2021 and ended on the date 22 April 2021 from Int'l Islamic University Chittagong, Bangladesh (longitude 91.720902539062 and Latitude 22.495181427788). The responses were coded in IBM SPSS Statistics 20 and IBM SPSS AMOS 22 software after necessary correction and modification for further analysis. The qualification of respondents for collected data is 25 Intermediates, 49 graduates, and 26 Masters. The intermediate qualification respondents are now the student of graduate, the graduate qualification respondents are now the student of masters and master's qualification respondents are now the teachers. All the respondents are directly involved in online classes during the coronavirus (COVID-19) pandemic situation. A systematic random sampling method is used to select respondents from 83 business schools and 17 from science and engineering schools. Among the respondents $63 \%$ use smartphones, $14 \%$ personal computers, $14 \%$ laptop, and 9\% tablet for an online class. Most of the respondents (79\%) use zoom for group communication. The rest of the respondents use Social networks (8\%), WhatsApp (7\%), and Google classroom (6\%). In the survey response data was collected from Metropolitan/ Divisional city (54\%), District town (18\%), Upazila/ Thana/ Equivalent (22\%) and Village area/ Rural are $(6 \%)$. The material used in online education is an online class $(51 \%)$, PDF lecture (30\%), online book (10\%), and Educational website (9\%). The descriptive analysis of values of each response variable is calculated. Factor analysis is conducted with all the response variables to classify them into challenge factors. Then Structure Equation Model (SEM) is developed to identify factors that are significant to performance.

\section{RESULT AND DISCUSSION}

The descriptive analysis of values for each response variable is calculated and shown in Table 1.

Table 1. Descriptive analysis of response variables

\begin{tabular}{|c|l|l|c|c|c|c|}
\hline $\begin{array}{l}\text { Serial } \\
\text { No. }\end{array}$ & Description of Questionnaire & $\begin{array}{l}\text { Variable } \\
\text { Name }\end{array}$ & Min & Max & Mean & $\begin{array}{l}\text { Standard } \\
\text { Deviation }\end{array}$ \\
\hline 1. & Performance of online learning & & & & & \\
\hline a. & Performance of teaching & Perform1 & 1 & 10 & 6.48 & 1.899 \\
\hline b. & Performance of instructor & Perform2 & 1 & 10 & 6.05 & 1.690 \\
\hline c. & Performance of learning & Perform3 & 1 & 10 & 6.42 & 1.804 \\
\hline d. & Performance of student & Perform4 & 3 & 10 & 6.16 & 1.581 \\
\hline e. & The flexibility of class time & Perform5 & 1 & 10 & 6.33 & 1.776 \\
\hline f. & Quality of learning & Perform6 & 3 & 10 & 6.19 & 1.587 \\
\hline 2. & Personal challenge & & & & & \\
\hline a. & Digital literacy & PersonCh1 & 1 & 10 & 6.60 & 1.959 \\
\hline b. & Software facility & PersonCh2 & 1 & 10 & 6.64 & 2.067 \\
\hline c. & Hardware facility & PersonCh3 & 1 & 10 & 6.49 & 1.883 \\
\hline d. & Self-motivation & PersonCh4 & 1 & 10 & 6.50 & 1.872 \\
\hline e. & Acceptability & PersonCh6 & 1 & 10 & 6.55 & 1.930 \\
\hline f. & Adaptability & & & & 6.55 & 1.930 \\
\hline 3. & Perceived challenge & PerceiveCh1 & 1 & 10 & 6.51 & 2.809 \\
\hline a. & Lack of common learning goal & PerceiveCh2 & 1 & 10 & 6.53 & 2.736 \\
\hline b. & $\begin{array}{l}\text { Lack of feedback from the } \\
\text { teacher }\end{array}$ & & & & & \\
\hline
\end{tabular}




\begin{tabular}{|c|c|c|c|c|c|c|}
\hline $\begin{array}{l}\text { Serial } \\
\text { No. }\end{array}$ & Description of Questionnaire & $\begin{array}{l}\text { Variable } \\
\text { Name }\end{array}$ & Min & Max & Mean & $\begin{array}{l}\text { Standard } \\
\text { Deviation }\end{array}$ \\
\hline c. & $\begin{array}{l}\text { Lack of feedback from a } \\
\text { classmate }\end{array}$ & PerceiveCh3 & 1 & 10 & 6.64 & 2.939 \\
\hline $\mathrm{d}$. & Lack of time to participate & PerceiveCh4 & 1 & 10 & 5.67 & 2.511 \\
\hline e. & $\begin{array}{l}\text { Lack of individual } \\
\text { accountability }\end{array}$ & PerceiveCh5 & 1 & 10 & 6.38 & 2.722 \\
\hline $\mathrm{f}$. & Misunderstanding of the topic & PerceiveCh6 & 1 & 10 & 6.53 & 2.743 \\
\hline g. & Off-topic discussion & PerceiveCh7 & 1 & 10 & 5.74 & 2.389 \\
\hline 4. & Task assignment challenge & & & & & \\
\hline a. & Lack of assessment task, quiz & TaskCh1 & 1 & 10 & 5.98 & 2.502 \\
\hline b. & Lack of effective counseling & TaskCh2 & 1 & 10 & 5.98 & 2.357 \\
\hline c. & Lack of open discussion & TaskCh3 & 2 & 10 & 5.99 & 2.298 \\
\hline d. & $\begin{array}{l}\text { Lack of face-to-face group } \\
\text { study }\end{array}$ & TaskCh4 & 2 & 10 & 6.09 & 2.336 \\
\hline e. & Lack of concentration & TaskCh5 & 2 & 10 & 6.11 & 2.339 \\
\hline f. & $\begin{array}{l}\text { The large class makes class } \\
\text { noisy }\end{array}$ & TaskCh6 & 1 & 10 & 6.10 & 2.509 \\
\hline g. & Time management problem & TaskCh7 & 1 & 10 & 6.05 & 2.293 \\
\hline 5. & Course curriculum challenge & & & & & \\
\hline a. & $\begin{array}{l}\text { Conceptual theoretical subjects } \\
\text { with critical thinking }\end{array}$ & CourseCh1 & 1 & 10 & 7.22 & 2.130 \\
\hline b. & $\begin{array}{l}\text { Theoretical subjects with a lot } \\
\text { of discussions }\end{array}$ & CourseCh2 & 1 & 10 & 6.64 & 2.484 \\
\hline c. & $\begin{array}{l}\text { Subjects with big mathematical } \\
\text { problems }\end{array}$ & CourseCh3 & 1 & 10 & 7.55 & 2.204 \\
\hline 6. & Technical challenge & & & & & \\
\hline a. & Mobile network & TechnCh1 & 1 & 10 & 5.81 & 2.304 \\
\hline b. & Internet speed & TechnCh2 & 1 & 10 & 5.67 & 2.693 \\
\hline c. & Cost of device & TechnCh3 & 1 & 10 & 5.59 & 2.594 \\
\hline d. & Load shading & TechnCh4 & 1 & 10 & 6.43 & 2.716 \\
\hline 7. & Social challenge & & & & & \\
\hline a. & $\begin{array}{l}\text { Anxiety regarding social } \\
\text { acceptance }\end{array}$ & SocialCh1 & 1 & 10 & 6.33 & 2.270 \\
\hline b. & $\begin{array}{l}\text { Anxiety regarding family's } \\
\text { financial crisis }\end{array}$ & SocialCh2 & 1 & 10 & 6.28 & 2.261 \\
\hline c. & $\begin{array}{l}\text { Anxiety regarding own future } \\
\text { and career }\end{array}$ & SocialCh3 & 1 & 10 & 7.06 & 2.335 \\
\hline d. & $\begin{array}{l}\text { Anxiety regarding the global } \\
\text { crisis }\end{array}$ & SocialCh4 & 1 & 10 & 7.01 & 2.443 \\
\hline
\end{tabular}

From the above descriptive analysis table, it is observed that the mean with a standard deviation of Performance of online learning variable value varies from 6.05 to $6.48 \pm 1.581$ to 1.899 , for Personal Challenge variable value varies from 6.49 to $6.64 \pm 1.872$ to 2.067 , for Perceived challenge variable value varies from 5.67 to $6.64 \pm 2.389$ to 2.939 , for Task assignment 
challenge variable value varies from 5.98 to $6.11 \pm 2.293$ to 2.509 , for Course Curriculum challenge variable value varies from 6.64 to $7.55 \pm 2.130$ to 2.484 , for Technical challenge variable value varies from 5.59 to $6.43 \pm 2.304$ to 2.716 and for Social Challenge variable value varies from 6.28 to $7.06 \pm 2.261$ to 2.443 . As the mean value and standard deviation value vary with overlapping each other, so factor analysis is conducted to test the questionnaire and to classify the questionnaire into challenge factor and the result is shown in Table 2.

Table 2. Factor analysis of response variables

\begin{tabular}{|c|c|c|c|c|c|c|c|c|c|}
\hline \multirow{3}{*}{$\begin{array}{l}\text { Factor } \\
\text { Name }\end{array}$} & \multicolumn{8}{|c|}{ Rotated Component Matrix } & \\
\hline & \multirow{2}{*}{$\begin{array}{l}\text { Variable } \\
\text { Name }\end{array}$} & \multicolumn{7}{|c|}{ Component } & \multirow{2}{*}{$\begin{array}{c}\text { Cronbach's } \\
\text { Alpha }\end{array}$} \\
\hline & & 1 & 2 & 3 & 4 & 5 & 6 & 7 & \\
\hline \multirow{6}{*}{$\begin{array}{l}\text { Personal } \\
\text { Challenge }\end{array}$} & PersonCh5 & .955 & & & & & & & \multirow[t]{6}{*}{0.990} \\
\hline & PersonCh2 & .949 & & & & & & & \\
\hline & PersonCh3 & .946 & & & & & & & \\
\hline & PersonCh4 & .944 & & & & & & & \\
\hline & PersonCh6 & .938 & & & & & & & \\
\hline & PersonCh1 & .925 & & & & & & & \\
\hline \multirow{7}{*}{$\begin{array}{l}\text { Perceived } \\
\text { Challenge }\end{array}$} & PerceiveCh3 & & .935 & & & & & & \multirow[t]{7}{*}{0.955} \\
\hline & PerceiveCh1 & & .919 & & & & & & \\
\hline & PerceiveCh6 & & .918 & & & & & & \\
\hline & PerceiveCh2 & & .913 & & & & & & \\
\hline & PerceiveCh7 & & .832 & & & & & & \\
\hline & PerceiveCh4 & & .830 & & & & & & \\
\hline & PerceiveCh5 & & .703 & & & & & & \\
\hline \multirow{7}{*}{$\begin{array}{l}\text { Task } \\
\text { assignment } \\
\text { Challenge }\end{array}$} & TaskCh1 & & & .947 & & & & & \multirow[t]{7}{*}{0.960} \\
\hline & TaskCh2 & & & .942 & & & & & \\
\hline & TaskCh7 & & & .933 & & & & & \\
\hline & TaskCh3 & & & .913 & & & & & \\
\hline & TaskCh4 & & & .828 & & & & & \\
\hline & TaskCh6 & & & .819 & & & & & \\
\hline & TaskCh5 & & & .811 & & & & & \\
\hline \multirow{6}{*}{$\begin{array}{l}\text { Performance } \\
\text { of online } \\
\text { Learning }\end{array}$} & Perform4 & & & & .926 & & & & \multirow[t]{6}{*}{0.966} \\
\hline & Perform2 & & & & .911 & & & & \\
\hline & Perform6 & & & & .902 & & & & \\
\hline & Perform1 & & & & .894 & & & & \\
\hline & Perform5 & & & & .892 & & & & \\
\hline & Perform3 & & & & .887 & & & & \\
\hline \multirow{4}{*}{$\begin{array}{l}\text { Technical } \\
\text { Challenge }\end{array}$} & TechnCh3 & & & & & .849 & & & \multirow[t]{4}{*}{0.871} \\
\hline & TechnCh2 & & & & & .809 & & & \\
\hline & TechnCh4 & & & & & .759 & & & \\
\hline & TechnCh1 & & & & & .683 & & & \\
\hline \multirow{3}{*}{$\begin{array}{l}\text { Social } \\
\text { Challenge }\end{array}$} & SocialCh1 & & & & & & .891 & & \multirow[t]{3}{*}{0.904} \\
\hline & SocialCh2 & & & & & & .890 & & \\
\hline & SocialCh3 & & & & & & .603 & & \\
\hline
\end{tabular}




\begin{tabular}{|c|c|c|c|c|c|c|c|c|c|}
\hline \multirow{3}{*}{$\begin{array}{l}\text { Factor } \\
\text { Name }\end{array}$} & \multicolumn{8}{|c|}{ Rotated Component Matrix } & \\
\hline & \multirow{2}{*}{$\begin{array}{l}\text { Variable } \\
\text { Name }\end{array}$} & \multicolumn{7}{|c|}{ Component } & \multirow{2}{*}{$\begin{array}{c}\text { Cronbach's } \\
\text { Alpha }\end{array}$} \\
\hline & & 1 & 2 & 3 & 4 & 5 & 6 & 7 & \\
\hline & SocialCh4 & & & & & & .600 & & \\
\hline \multirow{5}{*}{$\begin{array}{l}\text { Course } \\
\text { curriculum } \\
\text { Challenge }\end{array}$} & CourseCh2 & & & & & & & .821 & \multirow[t]{3}{*}{0.838} \\
\hline & CourseCh1 & & & & & & & .766 & \\
\hline & CourseCh3 & & & & & & & .598 & \\
\hline & \multicolumn{8}{|c|}{$\begin{array}{l}\text { Extraction Method: Principal Component Analysis. } \\
\text { Rotation Method: Varimax with Kaiser Normalization. }\end{array}$} & \\
\hline & \multicolumn{8}{|c|}{ a. Rotation converged in 6 iterations. } & \\
\hline
\end{tabular}

From the above factor analysis table, it is observed that the response variables are classified into seven groups based on the survey response values. The Cronbach's Alpha value of Personal challenge is 0.990, the Perceived challenge is 0.995, Task assignment challenge is 0.960, Performance of online learning is 0.966 , Technical challenge is 0.871 , Social challenge is 0.904 , and Course challenge is 0.838 . So, the collected survey response data and its classification of challenge factors are reliable and consistent (Cronbach's Alpha value > 0.7). In the factor analysis, the Kaiser-Meyer-Olkin Measure of Sampling Adequacy value is 0.784 (significance level 0.000). So, we can apply factor analysis for dividing the response variable into seven different factors. From Table 2, the factor leadings for Personal challenge is 0.925-0.955, Perceived challenge is $0.703-0.935$, Task assignment challenge is $0.811-0.947$, Performance of online learning is $0.887-$ 0.926 , Technical challenge is $0.683-0.849$, Social challenge is $0.600-0.891$ and Course challenge is $0.598-0.821$. It is observed that all factor loadings are greater than 0.400 , which expresses that all measurements for each factor have good reliability. Based on the factor analysis result, a structural equation model is developed (Figure 1).

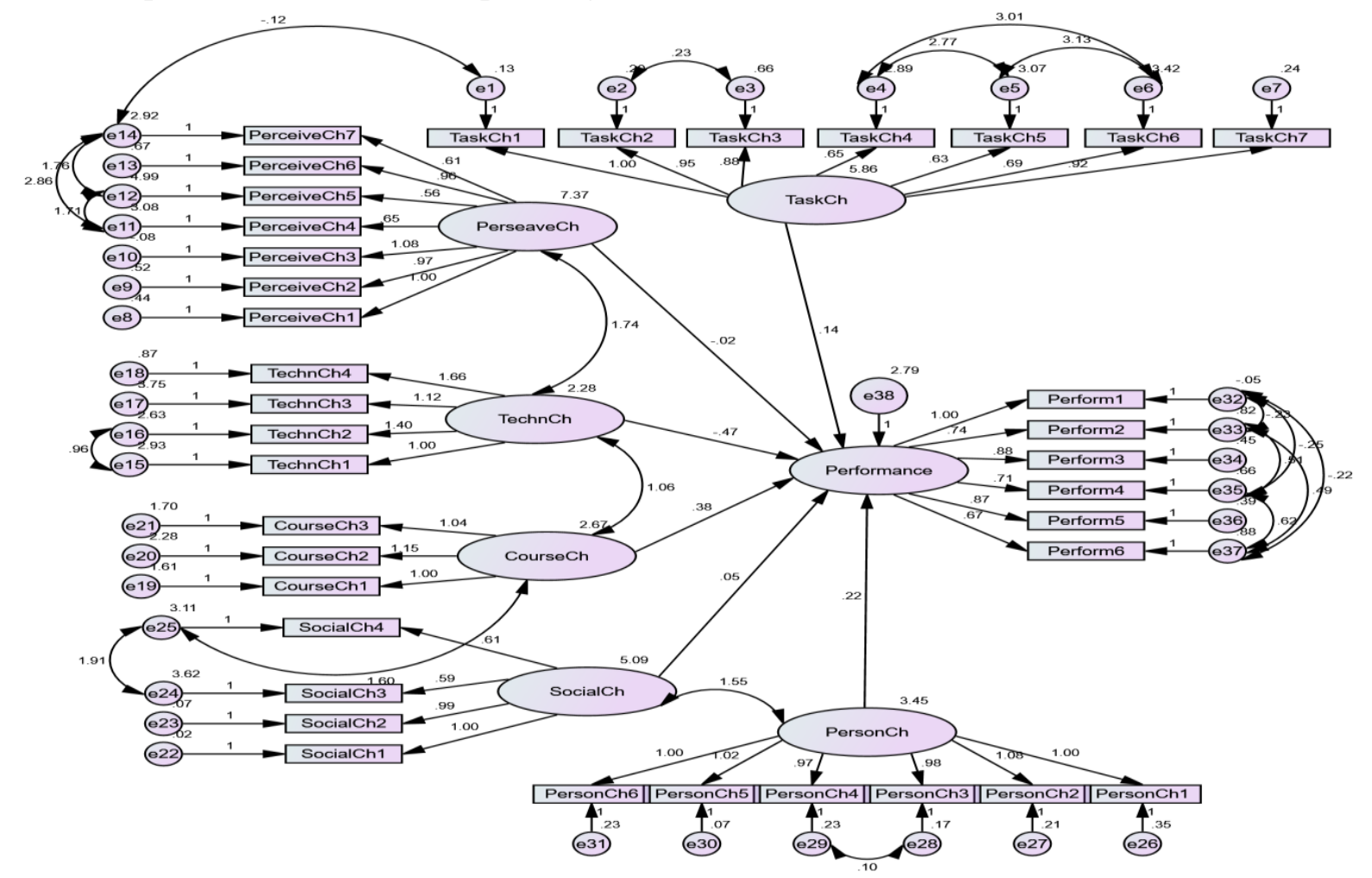

Figure 1. Structure Equation Model of online class challenge 
From the above structure equation model, the factor leadings for Personal challenge is 0.969-1.080, Perceived challenge is 0.564-1.082, Task assignment challenge is 0.633-1.000, Performance of online learning is $0.668-1.000$, Technical challenge is 1.000-1.665, Social challenge is $0.592-1.000$ and Course challenge is 1.000-1.152. All the factor loadings are very high and significant $(\mathrm{p}<0.05)$. The error variance for Personal challenge, Perceived challenge, Task assignment challenge, Performance of online learning, Technical challenge, Social challenge, Course challenge, and Performance are 0.072 to $0.348,-0.082$ to $4.995,0.130$ to $3.417,-0.050$ to $0.878,0.868$ to $3.754,0.016$ to $3.615,1.606$ to 2.280 and 2.794 respectively. The covariance values are -0.253 to 3.130 , which are also significant $(\mathrm{p}<0.05)$. In the model, $\chi^{2} / \mathrm{df}$ is 1.617 (which is < 3), comparative fit index (CFI) value is 0.942 (which is >0.9), Incremental fit index (IFI) is 0.942 (which is > 0.9), Tucker Lewis index (TLI) is 0.936 (which is > 0.9), Root Mean Square Error of Approximation is 0.79 (which is < 0.08). So, every index meets the standards of the survey and the model is a well-fitted model.

The path coefficient of Personal challenge to Performance of online learning is 0.219 ( $p=$ 0.024). Hypothesis 1 is rejected. So, the Personal challenge factor has a positive significant effect on the Performance of online learning.

The path coefficient of a Perceived challenge to Performance of online learning is -0.018 $(\mathrm{p}=0.802)$. Hypothesis 2 is accepted. So, the Perceived challenge factor has no significant effect on the Performance of online learning.

The path coefficient of the Task assignment challenge to Performance of online learning is $0.140(\mathrm{p}=0.041)$. Hypothesis 3 is rejected. So, the Task assignment challenge factor has a positive significant effect on the Performance of online learning.

The path coefficient of Technical challenge to Performance of online learning is -0.469 $(\mathrm{p}=0.004)$. Hypothesis 4 is rejected. So, the Technical challenge factor has a negative significant effect on the Performance of online learning.

The path coefficient of Social challenge to Performance of online learning is 0.053 ( $\mathrm{p}=$ 0.503). Hypothesis 5 is accepted. So, Social challenge has no significant effect on the Performance of online learning.

The path coefficient of Course challenge to Performance of online learning is $0.383(\mathrm{p}=$ 0.004). Hypothesis 6 is rejected. So, the Course challenge factor has a positive significant effect on the Performance of online learning.

\section{CONCLUSION}

The purpose of the study is to identify the factors that influence the performance of online education in Bangladesh. In this study, it is observed that the personal challenge factor, task assignment challenge factor, and course challenge factor have a significant positive contribution to the performance challenge factor in online education. Moreover, the technical challenge factor has a significant negative contribution to the performance challenge factor in online education. But perceive challenge factor and social challenge factor have no significant contribution to the performance challenge factor in online education. Hence the result finding may be utilized in the planning and utilization strategy of Government, University, College, and school teachers and students in the COVID-19 pandemic situation in the future to improve the performance of online education. Hence the researchers have a great opportunity to do more research to overcome these challenges to improve the efficiency of distance learning education in the pandemic situation. 


\section{REFERENCES}

Abidah, A., Hidaayatullaah, H. N., Simamora, R. M., Fehabutar, D., \& Mutakinati, L. (2020). The Impact of Covid-19 to Indonesian Education and Its Relation to the Philosophy of "Merdeka Belajar." Studies in Philosophy of Science and Education, 1(1), 38-49. https://doi.org/10.46627/sipose.v1i1.9

Bangert, A.W. (2006). Identifying factors underlying the quality of online teaching effectiveness: An exploratory study. Journal of Computing in Higher Education, 17(2), 79-99.

Basilaia, G., \& Kvavadze, D. (2020). Transition to online education in schools during a SARSCoV-2 coronavirus (COVID-19) pandemic in Georgia. Pedagogical Research, 5(4), 1-9.

Bennett, C.F., \& Monds, K.E. (2008). Online courses the real challenge is motivation. College Teaching Methods \& Styles Journal (CTMS), 4(6), 1-6.

Carey, K. (2020). Everybody ready for the big migration to online college? Actually, No. The New York Times, 13.

Cojocariu, V. M., Lazar, I., Nedeff, V., \& Lazar, G. (2014). SWOT analysis of e-learning educational services from the perspective of their beneficiaries. Procedia-Social and Behavioral Sciences, 116, 1999-2003.

Dhawan, S. (2020). Online Learning: A Panacea in the Time of COVID-19 Crisis. Journal of Educational Technology Systems, 49(1), 522.https://doi.org/10.1177/0047239520934018

Eom, S.B., Wen, H.J., \& Ashill, N. (2006). The determinants of students' perceived learning outcomes and satisfaction in university online education: An empirical investigation. Decision Sciences Journal of Innovative Education, 4(2), 215-235.

Fredericksen, E., Pickett, A., Shea, P., Pelz, W., \& Swan, K. (2000). Factors influencing faculty satisfaction with asynchronous teaching and learning in the SUNY learning network.

Gorsky, P., \& Blau, I. (2009). Online teaching effectiveness: A tale of two instructors. The International Review of Research in Open and Distributed Learning, 10(3).

Goto, S.T., \& Martin, C. (2009). Psychology of success: Overcoming barriers to pursuing further education. The Journal of Continuing Higher Education, 57(1), 10-21.

Gonzalez, T., De la Rubia, M. A., Hincz, K. P., Comas-Lopez, M., Subirats, L., Fort, S., \& Sacha, G. M. (2020). Influence of COVID-19 confinement on students' performance in higher education. $\quad P L o S \quad O N E, \quad 15(10 \quad$ October $), \quad 1-23$. https://doi.org/10.1371/journal.pone.0239490 
Govindarajan, V. \& Srivastava A. (2020). What the shift to virtual learning could mean for the future of higher ed. Harvard Business Review. Retrieved from https://hbr.org/2020/ 03/what-the-shift-to-virtual-learning-could-mean-for-the-future-of-higher-ed

Jasim, M.M. (2020). Private university students taking online classes. Retrieved from https://tbsnews.net/coronavirus-chronicle/covid-19-bangladesh/private-universitystudents-taking-online-classes-64867

Kop, R., Fournier, H., \& Mak, J.S.F. (2011). A pedagogy of abundance or a pedagogy to support human beings? Participant support on massive open online courses. International Review of Research in Open and Distributed Learning, 12(7), 74-93.

Kapasia, N., Paul, P., Roy, A., Saha, J., Zaveri, A., Mallick, R., ... Chouhan, P. (2020). Impact of lockdown on learning status of undergraduate and postgraduate students during COVID19 pandemic in West Bengal, India. Children and Youth Services Review, 116, 105194. https://doi.org/10.1016/j.childyouth.2020.105194

Karalis, T. (2020). Planning and evaluation during educational disruption: Lessons learned from Covid-19 pandemic for treatment of emergencies in education. European Journal of Education Studies, 7(4), 125-142. https://doi.org/10.5281/zenodo.3789022

Kumar, D. N. S. (2020). Impact of Covid-19 on Higher Education. Higher Education Digest. Retrieved from https://www.highereducationdigest.com/impact-of-covid-19-on-highereducation/

Krishnamurthy, S. (2020). The future of business education: A commentary in the shadow of the Covid-19 pandemic. Journal of Business Research, 117(May), 1-5. https://doi.org/10.1016/j.jbusres.2020.05.034

Means, B., Toyama, Y., Murphy, R., \& Baki, M. (2013). The effectiveness of online and blended learning: A meta-analysis of the empirical literature. Teachers College Record, 115(3).

Meyer, K., \& Jones, S. (2011). Information Found and Not Found: What University Websites Tell Students. Online Journal of Distance Learning Administration, 14(3).

Mishra, L., Gupta, T., \& Shree, A. (2020). Online teaching-learning in higher education during lockdown period of COVID-19 pandemic. International Journal of Educational Research Open, 1(June), 100012. https://doi.org/10.1016/j.ijedro.2020.100012

Muilenburg, L.Y., \& Berge, Z.L. (2005). Student barriers to online learning: A factor analytic study. Distance education, 26(1), 29-48.

Manzoor, A. (2020). Online Teaching and Challenges of COVID-19 for Inclusion of Persons with Disabilities in Higher Education. Retrieved from https://dailytimes.com.pk/595888/online- teaching-and-challenges-of-covid-19-forinclusion-of-pwds-in-higher-education/ 
Palden, T. (2020, August 12). Women test COVID-19 positive after five tests locking down entire country. Kuensel, 1-2.

Pokhrel, S., \& Chhetri, R. (2021). A Literature Review on Impact of COVID-19 Pandemic on Teaching and Learning. Higher Education for the Future, 8(1), 133-141. https://doi.org/10.1177/2347631120983481

Schrum, L., \& Hong, S. (2002). Dimensions and strategies for online success: Voices from experienced educators. Journal of Asynchronous Learning Networks, 6(1), 57-67.

Stallman, H.M. (2008). Prevalence of psychological distress in university students: Implications for service delivery. Australian Journal of General Practice, 37(8), 673.

Sujan, S. (2020). 63 universities taking online classes, $70 \%$ students, Bonik Barta. Retrieved from https://bonikbarta.net/home/news_description/228213

Singh, V., \& Thurman, A. (2019). How many ways can we define online learning? A systematic literature review of definitions of online learning (1988-2018). American Journal of Distance Education, 33(4), 289-306.

Strielkowski, W. (2020). COVID-19 pandemic and the digital revolution in academia and higher education. $\quad$ Preprints 2020, 2020040290. https://doi.org/10.20944/preprints202004.0290.v1.

Sintema, E. J. (2020, April 7). Effect of COVID-19 on the performance of grade 12 students: Implications for STEM education. EURASIA Journal of Mathematics, Science and Technology Education, 16(7). https://doi.org /10.29333/ejmste/7893

Tull, S. N. A. K. (2017). Social media and e-learning in response to seismic events : resilient practices. DEANZ the Journal of Open, Flexible, and Distance Learning, 21(1), 63-76.

Vijayraghavan, K. \& Mascarenhas, R. (2020). Asian paints raises staff salaries to boost morale. Retrieved from https://economictimes.indiatimes.com/news/company/corporatetrends/asian-paints-raises-staff-salaries-to-boost-morale/articleshow/75746239.cms

Zhu, X., \& Liu, J. (2020). Zhu, X., \& Liu, J. (2020). Education in and after Covid-19: Immediate responses and long-term visions. Postdigital Science and Education, 2(3), 695-699.

Zimmerman, J. (2020). Coronavirus and the great online-learning experiment: Let's determine what our students actually learn online. Chronicle of Higher education, Retrieved from https://www.chronicle.com/article/Coronavirusthe-Great/248216

\section{Copyrights}

Copyright for this article is retained by the author(s), with first publication rights granted to the journal. This is an open-access article distributed under the terms and conditions of the Creative Commons Attribution license (http://creativecommons.org/licenses/by/4.0/ 